\title{
Suriye Krizi Bağlamında Rusya'nın Suriye \\ Politikası
}

\section{Kübra CAĞLAR HEKIMOĞLU ${ }^{1}$}

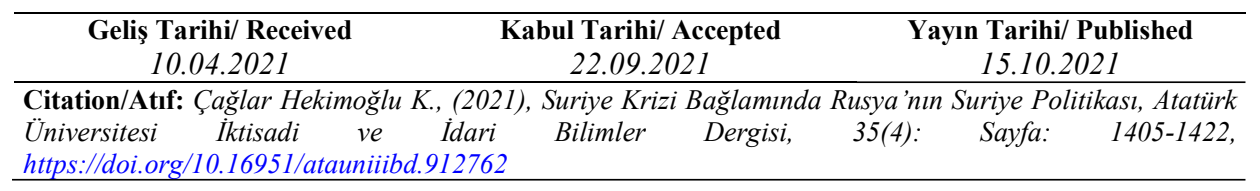

Öz: Arap dünyasında siyasi yozlaşma, baskıcı yönetim ve işsizlik gibi problemlere geniş kitlelerin tepki göstermesi ile başlayan Arap Baharı sürecinden Suriye de nasibini almış ve Mart 2011 'de iç savaş başlamıştır. Suriye'de otoriter Esad rejimine karşı halkın özgürlük ve demokrasi talepleri ile başlayan protestoları, Şam yönetiminin şiddete başvurarak bastırmaya çalışması ülkeyi krize sürüklemiştir. Yerel güçlerin yanı sıra bölgesel ve küresel aktörlerin de iç savaşa dahil olmasıyla Suriye krizi günümüze kadar devam eden kaotik bir hale bürünmüştür. Bu çalışmanın amacı, krizin en önemli aktörlerinden biri olan Rusya'nın Suriye politikasını analiz etmektir. Bu kapsamda, iç savaş öncesi ilişkilerdeki tarihsel derinlik dikkate alınarak Rusya'nın Suriye krizine yönelik yaklaşımı incelenmiştir. Rusya'nın Suriye politikasını belirleyen temel dinamikler tespit edilerek Suriye'de barışın inşa edilmesi sürecinde Rusya'nın rolü değerlendirilmiştir. Çalışmanın sonucuna göre, Rusya Suriye'ye yönelik izlediği politika sayesinde ulusal, bölgesel ve küresel hedeflerini gerçekleştirebilme noktasında zemin kazanarak dünya siyasetinde büyük güç statüsünü elde etmiștir.

Anahtar Kelimeler: Rusya, Suriye, Suriye İç Savaşı.

\section{Russia's Syria Policy in the Context of the Syrian Crisis}

Abstract: Syria also got its share from the Arab Spring, which started with the reaction of large masses to problems such as political corruption, oppressive governance and unemployment in the Arab world, and the civil war started in March 2011. Damascus administration's efforts to suppress the protests against the authoritarian Assad regime, which started with the people's demands for freedom and democracy, by using violence led to crisis in the country. With the involvement of local powers in the civil war as well as regional and global actors, the Syrian crisis has turned into a chaotic state that has continued until today. The purpose of this study is to analyse Russia's Syria policy, which is one of the most important actors of the crisis. In this context, Russia's approach to the Syrian crisis has been examined, taking into account the historical depth in precivil war relations. The fundamental dynamics that determine Russia's Syria policy have been revealed and Russia's role in the peace building process in Syria has been evaluated. According to the results of the study, Russia has gained the status of great power in world politics by gaining ground to realize its national, regional and global goals thanks to its policy towards Syria.

Keywords: Russia, Syria, Syrian Civil War.

Jel Codes: F50, F51, F59.

\footnotetext{
${ }^{1}$ Arş. Gör., Atatürk Üniversitesi, İktisadi ve İdari Bilimler Fakültesi, Uluslararası İlişkiler Bölümü, kubra.caglar@atauni.edu.tr,https://orcid.org/0000-0002-3019-5115
} 


\section{EXTENDED SUMMARY}

\section{Research Problem}

Understanding the role and goals of Russia, one of the most important actors of the Syrian crisis, which is one of the main problems of today's world, in this crisis is critical. Therefore, the aim of this study is to analyse Russia's policy towards Syria based on the Syrian crisis.

\section{Research Questions}

What are Russia's interests in Syria?

What are the reasons why Russia supports the Assad regime in Syria?

What is Russia's role in the political solution processes aimed at establishing peace in Syria?

What are the national, regional and global goals of Russia's Syria policy?

\section{Literature Review}

Emphasizing the continuity of Russia's attitude in Syria in order to reveal the basic parameters of Russian foreign policy, Allison (2013) examined this continuity through historical relations, identity, economic and geopolitical interests. He concluded that what maintains Moscow's alignment with Damascus is much more than a deep partnership with the Assad regime or the financial benefits it has achieved through this regime. Souleimanov and Abbasov (2020) questioned Russia's support for the Syrian government, which is at the stage of collapse, to regain control of the country. They claimed that Russia would gain little from the civil war in Syria and would have to deal with economic, political and social problems in Syria after the war. Blanga (2021) investigated Russia's interests in Syria and the reasons for its direct involvement in the civil war in Syria in 2015. According to the argument of his study, the Syrian civil war gave Russia a great opportunity to achieve its regional and global goals despite the USA.

\section{Methodology}

In this study, among qualitative research techniques, literature review and document analysis were used as a method. It has been tried to reach a conclusion by relating the obtained data with the historical background and current developments.

\section{Results and Conclusions}

When the obtained data is examined, it is seen that Russia, believing that the West was trying to surround itself with the Color Revolutions in its close vicinity, increased its influence in the region by having an active presence in Syria and it entered into a power competition with the West. Throughout the Syrian civil war, it supported the Assad regime militarily, economically and diplomatically, thus protecting its interests in the Middle East at the regional level 
and competing with the United States on a global scale. Thanks to its Tartus naval base in Syria, it gained the opportunity to land in the Mediterranean and took its place in the energy race in the Eastern Mediterranean. Moscow, supplying weapons to Syria, both promoted the weapons it produced and contributed to its economy. Thanks to the Astana and Sochi negotiations that it formed in order to end the crisis in Syria, it took the leading role in political solution processes by leaving the West out of the game. According to the results of the study, Russia has declared that it is a great power in the international arena by having the opportunity to realize its national, regional and global goals thanks to its policy in the Syrian crisis.

\section{Giriş}

Rusya'nın, Suriye bölgesine yönelik ilgisi yüzyıllar öncesine dayanıyor olsa da, iki ülke arasındaki güçlü ilişkiler Soğuk Savaş döneminde başlamıştır. $\mathrm{Bu}$ dönemde, daha çok ideolojik benzerlik ve Batı ile ilişkilerdeki sorunlar üzerinden başlayan taraflar arasındaki yakınlaşma, zamanla derinleşerek ivme kazanmıştır. Sovyetler Birliği’nin yıkılmasıyla ardılı olarak dünya sahnesinde yer alan Rusya, 2000'li yıllara kadar iç sorunlarıyla mücadele etmiş ve Suriye'ye yönelik ilgisi sınırlı düzeyde kalmıştır. 2000 yılında Vladimir Putin'in devlet başkanı olmasıyla iç politikada istikrarı yakalayan Rusya, dış politikada da etkin olmaya başlayarak Suriye ile olan ilişkilerine yeniden önem atfetmiştir (Ağır \& Takar, 2016). Özellikle 2007 yılındaki Münih Güvenlik Konferansı sonrası dış politikasını 'çok kutupluluk' ekseninde şekillendirerek Ortadoğu bölgesini, ABD’ye karşı manevra yapabileceği bir alan olarak görmüştür (Gülşen, 2018). Ortadoğu'da 2010 yılında başlayan Arap isyanlarından kaynaklı değişim sürecini sessiz bir şekilde takip eden Moskova, olayların Libya ve özellikle Suriye'ye sıçramasından dolayı kaygılanmıştır. Libya'da Kaddafi yönetiminin devrilmesi ve yeni yönetimin Kaddafi rejimiyle yapılan bütün anlaşmaları iptal etmesi Moskova yönetimini ekonomik açıdan büyük zarara uğratmıştır.

Suriye'de benzer bir durum yaşamamak ve çıkarlarını korumak isteyen Rusya, Suriye iç savaşında Beşar Esad rejiminin yanında yer alacaktır. Savaşın ilk yıllarında, rejimin devrilmemesi için Güvenlik Konseyindeki diplomatik tercihleriyle BM nezdinde gerçekleşebilecek askeri müdahale ihtimalini ortadan kaldıracaktır. Ardından, savaş gemilerini ve uçak gemisini bölgeye göndererek muhalif oluşumlara karşı mücadelede Esad rejimine askeri destek sağlayacaktır (Allison, 2013). 2013-2014 yıllarında Ukrayna ve Kırım'a ilgisini yoğunlaştırıp oradaki meseleleri hallederek, Eylül 2015'te Suriye iç savaşına doğrudan dahil olacaktır. Esad rejiminin yanında olduğunu uluslararası alanda ilan ederek, rejimi yıkmak isteyen Batı ile güç çekişmesi içine girecektir. Suriye'de elinde bulundurduğu Tartus deniz üssü üzerinden Doğu Akdeniz'de keşfedilen enerji kaynakları mücadelesinde etkinliğini arttıracaktır. Hmeymim hava üssüyle bölgedeki askeri kapasitesini arttırma şansını yakalayarak, Esad rejimi ile yaptığı silah ticareti sayesinde ekonomisini güçlendirecektir. Bu kazanımları koruyarak, 
Suriye'de kendi belirlediği çerçevede barış inşa etmek isteyerek, Astana ve Soçi süreçleriyle Suriye'deki iç savaşın sonlandırılmasına yönelik siyasi çözüm arayışında inisiyatif rol üstlenecektir (Dalar, 2017; Souleimanov \& Abbasov, 2020). Bu bağlamda çalışmada, Rusya'nın, Suriye ile iç savaş öncesi dönemdeki ilişkilerine değinilerek Suriye krizindeki rolü değerlendirilecektir. Aynı zamanda, Suriye'nin Rusya için arz ettiği önem irdelenerek Rusya'nın Suriye politikası incelenecektir.

\section{Soğuk Savaş Dönemi: İlişskilerde Tarihsel Derinlik}

II. Dünya Savaşı'nın ardından 1946 yılında Fransa'dan bağımsızlığını alan Suriye'nin, Sovyetler Birliği ile ilişkileri Şubat 1946'da yapılan gizli bir antlaşmayla başlamıştır (Aslanl, 2018: 2). Bu antlaşmaya göre, Sovyetler Birliği, Suriye'ye uluslararası alanda siyasi ve diplomatik açıdan destek olacak ve ülkede kurulması planlanan ulusal ordu için askeri eğitmen gönderecekti. Ayrıca, Fransız askerlerinin bölgeden temizlenmesi hususunda Suriye'ye arka çıkacak ve ülkenin tamamen yerel unsurların hâkimiyetinde kalması için yardımcı olacaktı. Ancak bağımsızlığını kazanmasının ardından birçok sorunla karşılaşan ve askeri darbeler yaşayan Suriye, iç politikada siyasi istikrarı yakalayamamıştır (Karabulut, 2007: 68-69). Bağımsızlık sonrası gerçekleşen darbelere, Şubat 1954'te bir yenisi daha eklenmiş ve ülkedeki Albay Edip Çiçekli iktidarına son verilmiştir (Dilek, 2017: 59). Bu darbenin ardından Suriye siyasetinde Baas Partisi ön plana çıkmış ve bu partinin ideolojisinin Pan-Arabizm ve sosyalizm eksenli olması, Suriye-Sovyetler Birliği ilişkilerinin doğal bir müttefiklik halinde ilerlemesine zemin hazırlamıştır.

Ortadoğu'da kurulan İsrail devletinin ABD ile yakın ilişkiler içinde olması, Sovyetler Birliği'nin Suriye'ye yönelmesi için uygun ortamı hazırlamıştır. Baas Partisi'nin komünizme olumlu bakan ve emperyalizm karşıtı ideolojisi, Suriye'yi Sovyetler Birliği'ne yakınlaştırmış ve iki ülke arasındaki derin ve çok boyutlu ilişkilerin temeli bu yıllarda atılmaya başlanmıştır (Sarıkaya, 2015: 3-5). 1957 yılında Sovyetler Birliği'nden silah yardımı almaya başlayan Suriye, 1970 yılında Hafız Esad'ın iktidara gelmesiyle Moskova yönetimi ile ilişkilerini en üst seviyeye taşımıştır. Ayrıca, 1970'te Mısır'da Enver Sedat'ın cumhurbaşkanı olması ve yeni yönetimin eksen değiştirerek ABD ile yakın ilişkiler geliştirmesiyle Sovyetler Birliği'nin Mısır ile olan yakın ilişkileri sona ermiştir. Yaşanan bu gelişmelerle, Sovyetler Birliği'nin Ortadoğu'daki tek ve en yakın müttefiki Suriye kalmıştır.

Hafiz Esad Suriye'de iktidara geldikten sonra, 1971 yılında, Moskova'ya bir ziyaret gerçekleştirmiş ve iki ülke arasında varılan anlaşmayla Akdeniz'e kıyısı bulunan Tartus deniz üssü Sovyet donanmasına verilmiştir (Karabulut, 2007: 72-75). 1980 yılında, iki ülke arasında çok önemli bir adım atılmış, Sovyetler Birliği-Suriye Dostluk ve İşbirliği Antlaşması imzalanarak barış ve güvenliğin tehdidi durumunda taraflar birbirinin garantörü olmayı teyit etmiştir. 1985 yllında Sovyetler Birliği'nde Gorbaçov'un iktidara gelmesinin ardından 
'glasnost' (açıklık) ve 'perestroyka' (yeniden yapılanma) politikalarının izlenmesi ve Batı dünyası ile ilişkilerde yumuşama yaşanması, Sovyetler Birliği'nin Ortadoğu'ya olan ilgisinin azalmasına yol açmıştır. Yavaş yavaş çözülmeye başlayan ve güç kaybeden Sovyetler Birliği, 1987'de Suriye'den danışmanlarını geri çekerek Ortadoğu'ya bir süre veda etmiş ve 1989'da dağılma sürecine girmiştir (Blanga, 2021: 67-68).

\section{Soğuk Savaş Sonrası Dönem: İlişskilerde Yeni Başlangıçlar}

1991'de Sovyetler Birliği'nin mirasçısı olarak uluslararası arenaya merhaba diyen Rusya, iç politikada siyasi, sosyal ve ekonomik sorunlarla karşılaşmıştır. Rusya'nın ilk devlet başkanı olan Boris Yeltsin'in liberal ekonomiye geçiş için 'şok terapi' uygulamalarını başlatması, ülkenin ekonomik ve sosyal yapısını derinden etkilemiş ve olumsuz sonuçlar doğurmuştur. Bu bağlamda, ülkede yoksulluk oranında ciddi bir artış yaşanmış ayrıca yolsuzluk ve rüşvet olayları çok sık karşılaşılan bir durum haline gelmiştir. Liberal ekonomiye geçiş sürecinde yapılan özelleştirmelerle zenginleşerek ortaya çıkan 'oligark' sınıfi, ekonomik ve siyasi olarak güçlenerek ülkede kontrolü ele geçirmiştir (Kotz \& Weir, 2012: 329-333).

İç politikada birçok problemle baş başa kalan Rusya, dış politikada 'Atlantikçi'2 yaklaşımı benimseyerek Batıcı bir çizgide yürümeyi tercih etmiştir. Bu bağlamda Dışişleri Bakanı Kozirev döneminde, ABD ve NATO bağlamında Batı dünyası ile olan ilişkilere önem verilmiş, Ortadoğu bölgesine yönelik ilgi oldukça geri planda kalmıştır. Dış politikada sürdürülen Batı yanlısı tavırdan halkın bir kısmının rahatsızlık duyması ve muhalif grupların ortaya çıkması, devlet başkanı Yeltsin'i daha sert bir tutuma yönlendirmiş ve 1993 yılında 'Yakın Çevre' doktrini ilan edilmiştir (Derman, 2016: 287-289). Bu doktrinle, Eski Sovyet ülkeleri üzerindeki hakimiyetini yeniden sağlamayı kendisine düstur edinen Rusya, 1996 yılında Primakov'un Dışişleri Bakanı olarak göreve gelmesiyle dış politikada 'Avrasyacı' çizgiye dönüş yapmıştır. İlan ettiği Yakın Çevre Doktrini ${ }^{3}$ ve diş politikadaki Avrasyacılık ${ }^{4}$ yönelimine rağmen bu planlar aslında kağıt üzerinde kalmış ve Rusya, 1990'lı yıllar boyunca Bağımsız Devletler Topluluğu coğrafyasında etkin bir aktör olamamıştır (Tellal, 2010).

2000 yılında Vladimir Putin'in devlet başkanı olarak seçilmesi, Rusya için değişim ve dönüşümün habercisi olmuş ve ülkenin toparlanma dönemi başlamıştır. Oligarkları kontrol altına alarak merkezi otoriteyi sağlayan Putin, o yıllarda enerji fiyatlarının da artış göstermesiyle ülkesinin ekonomisini düzlüğe

2 Rusya'nın gelişmesinin Batı dünyası ile ortak ilişki kurarak ve bütünleşerek gerçekleşebileceğini kabul etmektedir.

${ }^{3}$ Eski Sovyet devletlerinin oluşturduğu coğrafyanın ekonomi ve güvenlik bakımından hayati olduğunun ilan edilmesidir.

4 Rusya'nın, 'yakın çevresi'ni dış politikasının en öncelikli etki alanı olarak vurgulamasidir. 
çıkarmayı başarmıştır. Ekonominin toparlanması ve siyasi istikrarın sağlanmasıyla iç politikada buhranlı yılları geride bırakan Moskova, yeniden uluslararası arenada söz sahibi ülke konumuna ulaşmayı amaçlamıştır. Bu bağlamda, Yeltsin döneminde ihmal edilen özelde Suriye genelde Ortadoğu bölgesi, Putin döneminde yeniden önem kazanmış ve bölgeye yönelik aktif bir politika izlenmiştir (Issaev, 2021).

Gürcistan ile Ukrayna'nın Batı dünyasıyla yakınlaşan ilişkileri ve 20032005 yılları arasında meydana gelen 'Renkli Devrimler', Rusya'da çevrelenmişlik hissi uyandırmış ve Rusya 2007'deki Münih Güvenlik Konferansı'nda ABD tek kutupluluğunu eleştirmiştir. ABD hegemonyasına meydan okumaya başlayan Rusya, çok kutupluluğu dile getirmiş ve buna yönelik olarak da Ortadoğu ülkelerinden Suriye, İran, Libya gibi ülkelerle ilişkilerini geliştirmeye başlamıştır. 1990'lı yıllar boyunca ihmal ettiği, Ortadoğu'daki geleneksel müttefiki konumundaki Suriye'ye yeniden ilgi göstermeye başlayan Moskova, özellikle 2005 yılından itibaren Şam ile olan ilişkilerinde yeni bir sayfa açmıştır (Rezvani, 2020).

2005 yılında Suriye devlet başkanı Beşar Esad'ın, Moskova'da Putin ile yaptığı görüşme ikili ilişkiler açısından kritik önem teşkil etmiştir. Rusya'nın, Beşar Esad'ın Moskova ziyareti sonrasında Suriye'nin Sovyetler Birliği döneminden kalma borçlarının \%73'ünü silmesi, kalan borcunu da taksitlendirmesi, Rusya-Suriye ilişkilerinin yeniden canlanmasının önünü açmıştır. Gerçekleşen bu ziyaretle birlikte, ABD ve İsrail tarafından karşı çıkılmasına rağmen Rusya, Suriye'ye gelişmiş hava savunma sistemleri satışının sağlanması yönünde iradesini ortaya koymuştur. Ayrıca, Moskova yönetimi tarafindan 2.000 Rus askeri-teknik personeli Suriye'deki askerleri eğitmek için bölgeye gönderilmiştir (Kelkitli, 2016: 362-365).

Şubat 2005'te, Lübnan eski başbakanı Refik Hariri'nin suikasta uğraması sonucu hayatını kaybetmesinden dolayı Suriye siyaseti için buhranlı günler başlamıştır. Suriye'de muhalif gruplarla işbirliği içinde olan Hariri'nin ölümünden Şam rejimini sorumlu tutan Batılı ülkeler, Suriye'ye yaptırım uygulanması konusunu gündeme getirmiştir. Bu noktada devreye giren Moskova, Batılı ülkeler ile Suriye arasında denge bulmaya çalışarak Şam rejimi üzerindeki diplomatik baskıları hafifletmiştir (Ergun, 2018: 86). 2005 ve 2006 yıllarında Rusya ve Suriye arasında çok sayıda silah ve enerji anlaşmalarının imzalanması iki ülke arasındaki bağı kuvvetlendirmiştir. Suriye, Rus silah endüstrisi ve enerji şirketleri için sıcak para akışının sağlandığı pazar işlevini görmüştür. 2008 yılında Suriye ile varılan anlaşma doğrultusunda Rusya, Akdeniz'e kıyısı bulunan Tartus deniz üssünü genişleterek bu üssün modernizasyonunu sağlamıştır. 2010 yılında Şam'a bir ziyaret gerçekleştiren Medvedev, uluslararası arenada Suriye'nin arkasında olduğunu göstermiş ayrıca bu ziyaretle birlikte iki ülke arasında yeni silahlar hususunda görüşme sağlanmıştır (Çalışkan, 2018: 64-66). 


\section{Rusya'nın Suriye Krizine Yaklaşımı}

Aralık 2010'da Kuzey Afrika ve Ortadoğu'daki baskıcı ve otoriter rejimlere karşı başlayan protesto ve halk ayaklanmalarının ilk durağı Tunus ardından Mısır olmuştur. Bu olayların domino etkisi yaratarak Libya ve Suriye'de de baş göstermesinden oldukça rahatsızlık duyan Rusya, gelişmeleri yakından takip etmeye başlamışıtır. Suriye'nin Dera kentinde despot Şam yönetimine karşı başlayan protesto ve gösterileri, rejimin şiddet yöntemiyle bastırmaya çalışmasıyla, taraflar arasında silahlı mücadele başlamıştır. Esad güçleri ile muhalif unsurlar arasında devam eden mücadeleye zamanla dış aktörlerin de dahil olmasıyla iç savaş, günümüze kadar devam eden karmaşık bir sürece doğru evrilmiştir (Canyurt, 2018; Souleimanov \& Abbasov, 2020).

Rusya, Batılı güçlerin müdahalesi ve NATO operasyonuyla 2011'de Libya'da yaşanan yönetim değişikliğinin Suriye'de yaşanmaması için elindeki tüm imkanları kullanarak Esad rejimine destek olmuştur. Bu bağlamda, Ekim 2011'de Birleşmiş Milletler (BM) Güvenlik Konseyi'ne sunulan Suriye'ye yönelik yaptırımları öngören karar tasarısı Rusya ve Çin tarafından veto edilmiştir. Dışarıdan herhangi bir müdahaleyle ülkeye demokrasi gelmeyeceğini ifade eden Rusya, yaşanan olayları Suriye'nin iç meselesi olarak gördügünü ifade etmiştir. Esad rejiminin arkasında olduğunu, Kasım 2011'de üç savaş gemisini Tartus'a göndererek açık bir biçimde gösteren Rusya, ardından uçak gemisi Amiral Kuznetsov'u da Suriye'ye göndereceğini belirtmiştir. Esad rejiminin geleceğine Suriye halkının karar vermesi gerektiğini her firsatta dile getirerek bölgeye yönelik askeri bir müdahaleye karşı çıkmıştır. İki taraf arasındaki çatışmaların yoğunlaşması ve Esad rejiminin muhalif güçler üzerindeki baskı ve şiddetini arttırması üzerine Şubat 2012 ve Temmuz 2012'de BM Güvenlik Konseyi'ne önerilen karar tasarıları yine Rusya engeliyle karşılaşmıştır. Moskova bu şekilde, Suriye'ye karşı olası bir askeri müdahale seçeneğini BM Güvenlik Konseyi'ndeki diplomatik hamleleriyle rafa kaldırmıştır (Charap, 2013; İsmay1lov, 2015).

Batılı ülkeler, Ağustos 2013'te Şam'a yakın Doğu Guta bölgesinde kimyasal silahların kullanılmasıyla gerçekleşen saldırıda, çok sayıda insanın hayatını kaybetmesinden Esad yönetimini sorumlu tutmuştur. Obama yönetimindeki $A B D$ tarafından kırmızı çizgi olarak görülen kimyasal silah kullanımı iddiaları, Batılı ülkelerin Suriye'ye yönelik askeri operasyon söylemlerini gündeme getirmiştir. Kimyasal silah kullanımı hususundaki kanıtları ikna edici bulmayan Rusya, BM Güvenlik Konseyi'ne sunulan karar tasarısını Çin ile birlikte veto etmiştir (Sağlam, 2013: 211-212). Bunun yanında, Eylül 2013’te Suriye Dışişleri Bakanı Valid Muallem ile görüşen Rus Dışişleri Bakanı Sergey Lavrov, kimyasal silahların teslimi konusunda Suriye'yi ikna etmiştir. Ardından Cenevre'de bir araya gelen Sergey Lavrov ve John Kerry görüşmesi sonucunda Moskova-Washington hattında kimyasal silahların imhası ve uluslararası topluma teslim edilmesi hususunda mutabakata varılmıştır. 
Rusya'nın yoğun bir diplomasi yürüterek askeri güce başvurma seçeneğini önlemedeki başarısı, ABD'nin bölgedeki nüfuzunun sorgulanmasına yol açmıştır (Çalışkan, 2018: 76).

Suriye'deki krizin çözümüne yönelik uluslararası barış görüşmelerinin ilki 2012 yılında Batılı ülkeler öncülügüünde Cenevre'de gerçekleşmiştir. 2014'ün Ocak ayında yapılan II. Cenevre Konferansı'nda, taraflar arasında yaşanan fikir ayrılıklarından dolayı Suriye iç savaşına çözüm bulma konusunda tıkanıklıklar yaşanmıştır. Suriye'deki gelişmeler bu yönde ilerlerken, 2013 y1lının son aylarında başkent Kiev'de başlayan protesto ve ayaklanmalar Rusya'nın dikkatini Ukrayna krizine çekmiştir. Ukrayna cumhurbaşkanı Yanukoviç'in, Avrupa Birliği (AB) ile yapılması planlanan ortaklık anlaşmasını feshetmesiyle ülkedeki muhalifler protesto gösterilerine başlamıştır. Çatışmaların yoğunlaşmasıyla Yanukoviç ülkeyi terk ederken Mart 2014'te Kırım, önce bağımsızlığını ilan etmiş, ardından yapılan referandumla Rusya'ya bağlanma kararı almıştır. Ukrayna'da yaşanan gelişmelerden dolayı, ABD ve $A B$ ülkelerinin Rusya'ya ekonomik yaptırım uygulamaya başlamasına ek olarak o dönemde düşen petrol fiyatları, Rus ekonomisini oldukça olumsuz etkilemiştir. Batı tarafından uygulanan tüm yaptırımlara rağmen Rusya, Ukrayna'da istediğini elde etmiş, eski Sovyet coğrafyasındaki nüfuzunu korumak adına gerekirse askeri müdahale seçeneğini kullanabileceğini tüm dünyaya göstermiştir (Erşen, 2019; German, 2020).

Ukrayna krizi ve Kırım'ın ilhakından sonra ilgisini tekrardan Suriye'ye doğru çeviren Rusya, Mayıs 2014'te Esad'ın işlemiş olduğu savaş suçlarından dolay1 Uluslararası Ceza Mahkemesi'nde yargılanmasını öngören BM nezdindeki karar tasarısını onaylamamıştır. DAEŞ'in, 2014 yılında Suriye'nin pek çok bölgesinde etkinliğini arttırması ve hakimiyet alanını genişletmesiyle, iç savaşın seyri Esad rejimi aleyhine dönmeye başlamıştır. Ağustos 2014'te DAEŞ'e karşı mücadele kapsamında ABD önderliğinde kurulan uluslararası koalisyonun başlattığı hava operasyonları yeterince başarılı olamamış ve DAEŞ'in bölgedeki varlığı, Rusya tarafindan büyük bir tehdit unsuru olarak görülmüştür (Dalar, 2017: 170-172). 2015'in ilk yarısında, DAEŞ'in bölgede etkinliğini yoğunlaştırmasına ilaveten muhaliflerin İdlib'in kontrolünü ele geçirmesi ve Lazkiye'ye yönelmesi Esad rejimine toprak kaybettirmiştir. Yaşanan bu gelişmelerden endişe duyan Rusya, bölgeye yeni savaş uçakları, saldırı helikopterleri, hava savunma sistemleri ve insansız hava araçları göndererek bölgedeki askeri kapasitesini arttırmıştır (Maher \& Pieper, 2020: 79). 30 Eylül 2015 tarihinde Rus askeri birliklerinin Suriye'ye gönderilmesi konusunda Federasyon Konseyi'nden onay olan Rusya, Suriye'de hava operasyonlarına başlamıştır (Osborn \& Stewart, 2015, 30 Eylül). Fiili olarak Suriye'deki iç savaşa müdahil olan Rusya, bölgeye Esad rejiminin çağrısıyla geldiğini ve hava operasyonlarını DAEŞ'e karşı mücadele kapsamında yürüttüğünü açıklamıştır. Rusya'nın askeri müdahalesi ile Halep ve Hama 
bölgeleri rejimin kontrolüne geçmiş ve iç savaştaki dengeler Şam yönetimi lehine değişmiştir (Pieper, 2019: 374-375).

\section{Rusya'nın Suriye Politikasını Belirleyen Temel Dinamikler}

Rusya'nın Suriye politikasını belirleyen temel dinamiklerin başında ABD ile sürdürdüğü küresel liderlik mücadelesi gelmektedir. Soğuk Savaş sonrası dönemin ilk yıllarında ABD liderliğindeki Batılı güçler Ortadoğu bölgesinde etkinliğini arttırırken Rusya, yaşadığ kendi kabuğuna çekilerek bölgeye yönelik net bir duruş sergileyememiştir. ABD karşısında eski gücünü kaybettiğini düşünen Rusya, Libya'da yaşanan gelişmeleri de göz önünde bulundurarak, Suriye'yi bu gidişata son vermek adına önemli bir firsat olarak görmüştür (Erşen, 2017: 149). Kaddafi rejimi ile muhalif kuvvetler arasında yaşanan iç savaşta şiddet olaylarının artmasıyla Libya'da hava operasyonlarına başlayan Batılı güçler ve NATO, bu operasyonu BM Güvenlik Konseyi kararına dayandırdığını beyan etmiştir (Zvyagelskaya, 2018: 125). BM Güvenlik Konseyi’nin Mart 2011 tarihli ve 1973 sayılı kararı için çekimser oy kullanan Rusya, Batılı güçlerin bölgeye yönelik askeri müdahalesiyle kendisini deyim yerindeyse kandırılmış hissetmiştir. 1973 sayılı kararı, Rusya'nın hesaplamadığı bir şekilde hukuki güvence olarak gören Batılı güçler, uluslararası bir koalisyon oluşturarak Kaddafi rejimini devirmiştir (Allison, 2013: 798). Libya'da kurulan yeni hükümetin, Rusya ve Kaddafi rejimi arasında yapılan bütün askeri-teknik anlaşmaları iptal etmesi, Rusya'yı ekonomik açıdan büyük bir kayba uğratmıştır. Rusya, Libya olayından edindiği tecrübe ile Suriye iç savaş boyunca BM Güvenlik Konseyi'ndeki veto hakkını kullanarak Suriye'ye olası bir askeri müdahale seçeneğini engellemiştir (Ermağan \& Yılmaz, 2015: 669-670).

Rusya'nın ABD karşısında zemin kazanarak Ortadoğu denklemindeki yerini kuvvetlendirmesinde, Obama yönetiminin Suriye iç savaşı boyunca izlediği pasif politika oldukça belirleyici olmuştur. ABD yönetimi Suriye'deki terörist grupları yok etmek için bölgedeki ılımlı muhalifleri eğitmiş ancak harcanan milyarlarca dolara rağmen eğit-donat programı arzu edilen başarıyı yakalayamamıştır. Ayrıca, bölgede ABD liderliğinde oluşturulan DAEŞ karşııtı uluslararası koalisyonun gerçekleştirdiği hava operasyonlarından etkili sonuçlar alınamamıştır. Suriye iç savaşının doğurduğu mülteciler meselesinin $A B$ ülkeleri açısından ciddi bir kriz yaratması ve Rusya'nın 2015'teki müdahalesi sonrası bölgede daha aktif olarak varlık göstermesi, Rusya ve Batılı ülkeleri birlikte çözüm masasına oturtmuştur. Şubat 2016'da yapılan III. Cenevre görüşmelerinde Washington ile birlikte aktif rol oynayan Rusya, ABD karşısında mevzi kazanarak küresel çaptaki hedeflerine ulaşma noktasında ciddi bir aşama kaydetmiştir (Pieper, 2019).

Rusya'nın Suriye politikasını belirleyen diğer dinamik, Ortadoğu bölgesindeki askeri ve ekonomik çıkarlarıdır. 2015'in Ocak-Ağustos döneminde, DAEŞ ve muhalif gruplar karşısında toprak kaybederek sıkışan Esad rejiminin imdadına Moskova yönetimi yetişmiştir. Esad rejimini yerinde tutmak için Eylül 
2015 'te Suriye iç savaşına doğrudan dahil olan Rusya, bölgedeki siyasi dengeleri rejim lehine değiştirmeyi başarmıştır (Blanga, 2021: 62-63). Rusya, Suriye'ye yönelik müdahalesinde Irak ve İran'ın hava sahasını kullanırken kara gücü olarak da İran ve Hizbullah'tan faydalanmıştır. Bu noktada, Moskova'nın Ortadoğu ülkeleriyle geliştirdiği iyi ilişkiler de ön plana çıkmıştır. Kaddafi yönetimindeki Libya ile tesis ettiği askeri ve ticari ilişkiler sayesinde Rusya, silah ve petrol şirketleri lehine önemli kazanımlar elde etmiştir. Ayrıca, İran'ın nükleer programı bağlamında 2015 yılında P5+1 ülkeleriyle varılan anlaşma sonrasında, Moskova yönetimi İran'a S-300 füzelerini gönderme yönünde irade sergilemiştir. Buna ek olarak, iki ülke İran'ın Buşehr kentinde faaliyet gösteren nükleer santrale ikinci bir reaktör inşa edilmesi noktasında mutabakata vararak aralarındaki ilişkiyi güçlendirmiştir (Erşen, 2019: 75-76).

Rusya'nın Suriye politikasını şekillendiren bir diğer faktör ise Suriye'de rejime karşı savaşan radikal dini grupların, Rusya'nın ulusal güvenliğini tehdit etmesidir. Şöyle ki, dini gruplardaki militanların Orta Asya ve Kafkasya kökenli olması ve bu grupların zamanla eski Sovyet coğrafyasına doğru genişleyerek bölgeyi etkileme olasılığı, Rusya'nın toprak bütünlüğ̈̈ açısından tehlike arz etmektedir. Kuzey Kafkasya bölgesinde yaşanan etnik/dini mücadeleler ve Rusya'da yaşayan Müslüman nüfus düşünüldügünde Moskova yönetimi için durumun hassasiyeti ortadadır. Dolayısıyla, Ortadoğu'daki radikal dini örgütlenmelerin bölge dışına yayılması ihtimali Rusya'nın güvenliğini doğrudan etkilemekte ve Moskova yönetimi bölgede yaşanan gelişmelere ilgisiz kalamamaktadır (Aksoy, 2019: 68).

Rusya'nın Suriye'ye yönelik izlediği politikaya yön veren en önemli dinamiklerden birisi de Suriye'nin Akdeniz kıyısında bulunan Tartus deniz üssüdür. Suriye'nin Tartus şehrinde bulunan bu üs, aslında teknik donanım merkezi olup Rus gemilerinin bakım ve onarım işlerinin görüldüğü yerdir. Rusya'nın Ortadoğu'ya ve Akdeniz'e açılan kapısı olan Tartus deniz üssü, 1971'de Suriye ile yapılan anlaşma doğrultusunda Sovyetler Birliği'ne verilmiştir (Yılmaz, 2016: 159-161). Tartus üssü, 2008 yılında Moskova yönetimi tarafından genişletilerek modernize edilmiştir. 2017 yılında, Tartus limanının kullanımının 49 yıl daha Rusya'da kalması ve daha sonrasında tarafların aynı şekilde devam etmesini istemesi halinde anlaşmanın 25 yıl daha uzatılabileceği hususunda Moskova ve Şam yönetimi arasında anlaşma sağlanmıştır. Bu gelişmeler, Rusya'nın Ortadoğu'da ve Doğu Akdeniz'de kalıcı olmayı planladığının sinyallerini vermektedir. Son yıllarda Doğu Akdeniz'de yaşanan enerji mücadelesi düşünüldüğünde, Rusya'nın Akdeniz'deki varlığ büyük önem taşımaktadır. Bu bağlamda Moskova, yakın çevresi dışındaki tek üssü olan Tartus'a stratejik önem atfederek Doğu Akdeniz'de kurulacak yeni enerji denkleminde yerini almak istemektedir. Esad rejiminin yönetimden uzaklaşması durumunda bu üssü ve Akdeniz'deki çıkarlarını kaybedeceğini 
düşünen Rusya, Esad rejimine olan desteğini sürdürmektedir (İnat, 2019, 23 Ocak).

Rusya'nın Suriye'de Lazkiye şehri yakınlarında Hmeymim adında hava üssü de bulunmaktadır. 2015 yılında inşa edilen ve Basil Esad Havalimanını kapsayan bu üs üzerinden Rusya, Suriye'ye yönelik askeri operasyonlarını yürütmektedir. 2017 yılında taraflar arasında yapılan anlaşma uyarıca, Hmeymim hava üssü Rusya tarafından 49 yıllığına kiralanmış ve her iki tarafın da uygun bulması halinde anlaşmanın 25'er yıllık periyotlarla uzatılması konusunda mutabık kalınmıştır. Hmeymim hava üssü ile bölgeye çok sayıda savaş uçakları, saldırı helikopterleri ve hava savunma sistemleri konuşlandıran Rusya, bu üs sayesinde Suriye'deki askeri varlığını yoğunlaştırmıştır. Asker ve mühimmatıyla bugün Rus hava üssü durumunda olan Hmeymim, Moskova yönetiminin çıarlarına hizmet etmektedir (Souleimanov \& Dzutsati, 2018: 44-45).

Rusya'nın Suriye politikasını şekillendiren bir başka dinamik ise iki ülke arasındaki silah ticaretidir. Soğuk Savaş döneminde Suriye, Libya, Irak ve Mısır gibi Ortadoğu ülkeleriyle silah ticaretinde bulunan Rusya'nın, 1990'l1 yıllar boyunca bölge ülkelerine yönelik gerçekleştirdiği silah ihracatında azalma kaydedilmiştir. 2000 y1lında Putin'in devlet başkanlığı görevine gelmesiyle savunma sektörünü geliştiren Rusya, Ortadoğu'daki geleneksel müttefiki olan Suriye'ye silah satışını da arttırmıştır. Suriye'de yaşanan kriz ve istikrarsızlığı lehine çevirmiş, Esad rejimine sattığ silahlar sayesinde ciddi ekonomik kazanımlar elde etmiştir (Samoylov, 2018: 81-85). Esad rejiminin ayakta kalması için sahip olduğu silahları bölgede kullanan Rusya, İsrail'in bütün itiraz ve baskılarına rağmen S-300 füzelerinin Suriye'ye satışını gerçekleştirmiştir. Ayrıca, Suriye'ye yönelik gerçekleştirdiği askeri operasyon sonrasında İran, Irak, Suudi Arabistan, Katar, Mısır, Çin, Hindistan gibi ülkelere silah satışı artan Rusya, bu ülkelerle yeni silah anlaşmalarını gündemine almıştır. Silah teknolojisini Suriye topraklarında deneyerek yeni ürettiği silahların tanıtımını yapmıştır. Ortadoğu bölgesi Rus silahları için en büyük pazar işlevi görürken, Suriye de bu silahların en önemli alıcılarından birisi olmuştur (Kemaloğlu, 2013).

\section{Rusya'nın Suriye Krizine Yönelik Siyasi Çözüm Arayışları: Astana Süreci ve Soçi Görüş̧meleri}

Mart 2016'da askeri birliklerinin büyük bir kısmını Suriye'den geri çekmeye başlayan Putin yönetimi, Hmeymim ve Tartus üslerindeki Rus askeri varlığının devam edeceğini bildirmiştir (Unnikrishnan \& Purushothaman, 2017: 254). Suriye'ye müdahalesinden sonra sahada askeri etkinliğini arttıran Rusya, buna paralel olarak masada da etkin olmak istemiştir. Bu bağlamda, Aralık 2016 'da Suriye iç savaşının çözümüne yönelik olarak bölge ülkelerinden Türkiye ve İran ile bir araya gelerek Moskova mutabakatını imzalamıştır. Söz konusu mutabakata göre, Aralık 2016'da Suriye'de ilan edilen ateşkesin ardından Ocak 2017'de Kazakistan'ın başkenti Astana'da görüşmelere başlanmıştır (Köstem, 2017). 23 Ocak 2017'de Rusya, İran ve Türkiye öncülüğünde başlayan Astana 
görüşmeleri, ateşkes ve taraflar arası diyaloğun sağlanması hususuna odaklanmıştır (BBC, 2017, 24 Ocak). Suriye krizinde aktif rol oynayan bölge ülkelerinin yanı sıra DAEŞ, YPG ve Şam'ın Fethi Cephesi dışındaki silahlı grupların temsilcilerinin de Astana sürecinde yer alması, ateşkesin devam ettirilmesini sağlayarak görüşmelerin başarısını arttırmıştır (Köstem, 2017: 19).

Suriye'deki iç savaşı sona erdirmek için 2012 yılında Batı'nın güdümünde başlatılan Cenevre Görüşmelerinin kalıcı ateşkesi sağlayamaması ve savaşın ivme kazanarak devam etmesi, 2017 yılında Astana'ya giden sürece zemin hazırlamıştır. Suriye'de kalıcı barış rüzgarlarını estirebilmek için Cenevre'nin aksine daha az aktörlü bir girişim olan Astana Görüşmeleri, Rusya, Türkiye ve İran garantörlügünde öncelikle silahlı çatışmaları sona erdirmeyi ve kalıcı ateşkesi sağlamayı amaçlamıştır. Rejim güçleri ve muhalifler arasında yaşanan askeri ihtilaflara nokta koyarak siyasi çözüm aşamasına geçmeyi hedefleyen Astana sürecinde, ateşkesi takip etmek için üçlü mekanizma oluşturulması yönünde karar alınmıştır. Ayrıca, Suriye'deki terör örgütlerini elimine etmek ve Suriye'nin toprak bütünlüğünü korumak Astana kapsamında ulaşılmak istenen diğer gayeler olmuştur (Dieckhoff, 2020).

Astana görüşmelerine paralel bir şekilde, Suriye'nin geleceğine yönelik Kasım 2017'de yapılan Soçi Zirvesi'nde Rusya, İran ve Türkiye devlet başkanları bir araya gelmiştir. Zirvenin ardından Şam yönetimi ve muhalifleri aynı zeminde buluşturacak Suriye Ulusal Diyalog Kongresinin yapılacağı duyurulmuştur (Örmeci \& Kısacık, 2018: 259). Ocak 2018'de taraflar arasında gerçekleşen söz konusu kongrede, Suriye'nin geleceğinin şekillenmesi için en önemli adımlardan biri olan Suriye Anayasa Komitesi'nin kurulmasına karar verilmiştir. Daha sonra yapılan görüşmelerde, oluşturulacak komitenin yüz elli kişi olmasına ve bu komitenin ellisinin rejim güçlerinden, ellisinin muhalif gruplardan diğer ellisinin de BM/tarafsız isimlerden seçilmesi hususunda uzlaşı sağlanmıştır. Suriye meselesinde farklı grupları temsil eden kişilerden oluşan komite, krize siyasi çözüm geliştirmek amaciyla İsviçre'nin Cenevre kentinde görüşmeler gerçekleştirmektedir (ALJAZEERA, 2021, 25 Ocak).

İç savaşta muhalif grupların eline geçen İdlib, Dera, Doğu Guta, Hama ve Humus yerleşim yerleri Mayıs 2017'de yapılan Astana Zirvesi'nde 'çatışmasızlık bölgeleri' olarak kabul edilmiştir. Çatışmasızlık bölgelerinin ilan edilmesiyle bahse söz konusu olan alanlarda, askeri çatışmaların sonlandırılması ve bu bölgelere insani yardımların ulaştırılması amaçlanmıştır. Fakat radikal grupların varlı̆̆ını öne süren rejim kanadı, İdlib dışındaki tüm çatışmasızlık alanlarını ele geçirmiş ve ülkedeki hakimiyet alanını genişletmiştir. Rejim güçlerinin yürüttügüü askeri operasyonlar neticesinde söz konusu alanlardaki sivil insanlar ve silahlı grupların çoğu İdlib'e ve Türkiye'nin kontrolündeki güvenli bölgelere kaydırılmıştır. Çatışmasızlık bölgelerini bir bir ele geçiren rejim güçlerinin bir sonraki durağının İdlib olacağının sinyallerini alan Türkiye, olası bir göç 
dalgasının önüne geçmek için Moskova ile masaya oturarak Eylül 2018'de Soçi Mutabakatı'nı imzalamıştır (Orhan, Haş1, Dündar \& Şanlıer, 2020: 6-10).

Soçi mutabakatı metnine göre, çatışmasızlık bölgesi olan İdlib'in çevresinde $15-20 \mathrm{~km}$ derinliğe sahip bir hatta 'silahlardan arındırılmış bölge' kurulması hususunda anlaşma sağlanarak bu bölgede Rus ve Türk birliklerinin ortak devriye yapması kararlaştırılmıştır. Rejim güçleri ve muhalifler arasında sağlanması için uzlaşılan ateşkes ortamını güvence altına almak için Türk, Rus ve İran askeri gözlem noktaları oluşturulması noktasında mutabık kalınmıştır. Ayrıca M-4 ve M-5 karayollarının ulaşıma açık olacağı noktasında anlaşma sağlanmıştır (Tsvetkova, 2018, 17 Eylül). Soçi mutabakatına rağmen İdlib'de terör örgütleri olduğunu öne sürerek ateşkesi bozan rejim kanadı, askeri operasyonlarını gerçekleştirmeye devam etmiştir. Rusya, Türkiye ile yaptığı Soçi mutabakatına riayet etmeksizin Şam rejiminin gerçekleştirdiği operasyonlara sessiz kalmanın çok ötesinde bir tavır sergileyerek havadan destek sağlamıştır. Rusya'nın yanında, İran milis ordularının kara gücü desteğini de alan Şam yönetimi Mayıs 2019'da kara saldırılarına başlamıştır. Kasım 2019'dan itibaren yeniden şiddetlenen İdlib'e dönük operasyonlar Şubat 2020'ye kadar sürmüştür (Mevlütoğlu \& Korkmaz, 2020: 4-7).

Rusya'nın desteklediği Şam rejiminin, İdlib'e yönelik gerçekleştirdiği askeri operasyonlarının şiddetini arttırması ve Şubat 2020'de otuzun üzerinde Türk askerinin yaşamını yitirmesi üzerine Türkiye, Bahar Kalkanı Harekatını başlatmıştır. Bahar Kalkanı Harekatı, Türkiye ve Rusya arasında 5 Mart 2020'de yapılan Moskova mutabakatı ile son bulmuştur (Soldatkin \& Kiselyova, 2020, 5 Mart). Söz konusu mutabakat ile yeni ateşkes sınırları belirlenmiş ve askeri faaliyetlerin durdurulması kararı alınmıştır. M-4 otoyolunda güvenli koridor oluşturulması ve Rusya ile Türkiye'nin ortak devriye gerçekleştirmesi hususunda uzlaşma sağlanmıştır. Ayrıca, Halep'i Şam'a bağlayan M-5 otoyolunun kontrolü rejim kuvvetlerine bırakılmıştır. Rusya, Moskova mutabakatı ile Şam rejiminin ülkedeki saha hakimiyetini genişletmesine meşru bir zemin sağlamıştır. Mutabakat, İdlib'de yaşanan sıcak çatışmaları kısa bir süreliğine sonlandırsa da kalıcı bir çözüm sağlayamamıştır (Roth, 2020, 5 Mart).

Suriye'deki krizin onuncu yılında sahada oluşan tablo, Şam yönetiminin ülkenin büyük bir kısmını kontrolü altına aldığını göstermektedir. Elde ettiği alan hakimiyeti üstünlüğüyle uluslararası sisteme tekrardan entegre olmaya çalışan Esad rejimi, öncelikle Ortadoğu ülkeleri olmak üzere birçok ülkeyle ilişkilerinde normalleşme adımları atmaya başlamıştır. İç savaşın beraberinde getirdiği ekonomik çöküşü dış dünyayla temas kurarak aşmaya çalışan rejim, ABD'nin Sezar Suriye Sivil Koruma Yasası kıskacına takılmıştır. Haziran 2020'de yürürlüğe konulan söz konusu yasa, işlediği savaş suçları nedeniyle Esad rejimini ve rejime mali, askeri, teknolojik destek sağlayan kişi ve kurumları hedef almıştır. Dolayısıyla Sezar yasası, hem Esad rejimini hem de rejimin en büyük dayanağı olan Moskova yönetimini köşeye sıkıştırmıştır (Madouni \& Derradji, 2020). 
Çıkarları gereği Şam yönetiminin ülkenin bütünü üzerinde yeniden egemen olmasını isteyen Moskova, Fırat'ın doğusunun büyük bir kısmını kontrol eden PYD/YPG üzerinde etkin olmaya çalışmaktadır. Ancak ABD'nin PYD/YPG ile olan güçlü bağları, Rusya'nın bu arzusuna set çekerek rejimin Fırat'ın doğusuna hakim olma çabalarını etkisiz kılmaktadır. Moskova yönetimi ise bölgedeki $\mathrm{ABD}$ varlığını yok ederek Esad rejiminin ülkenin tamamına hakim olmasını sağlamak için PYD/YPG ile olan ilişkilerini derinleştirmeye çalışmaktadır (Haş11, 2021a: 58-59). Bu bağlamda Rusya, Ağustos 2020'de kendisine yakın bir oluşum olan Halkın İradesi Partisi (HIP) ile PYD/YPG'nin siyasi kanadı olan Suriye Demokratik Meclisi'ni Moskova'da bir araya getirmiştir (North Press Agency, 2020, 31 Ağustos). Rusya, bu girişimiyle, PYD/YPG'yi ABD hakimiyetinden uzaklaştırarak rejim unsurlarına dahil etmek istese de taraflar arasındaki gerilimli süreç devam etmektedir. 2021 yılı itibarıyla PYD/YPG ve rejim güçleri arasında ulaşım yollarının kontrolü ve buğday, akaryakıt gibi temel ürünlerin tedariki hususunda tansiyon yükselmektedir. Suriye'deki krize Rusya'nın öncülük ettiği uluslararası platformlar olan Astana ve Soçi süreçleri ve bu süreçlerin kazandırdığı Suriye Anayasa Komitesi'nin çalışmalarıyla çözüm üretilmeye çalışılmasına rağmen kısa vadede Suriye'de siyasi bir bütünlüğü ve kalıcı barışı öngörmek kolay değildir (Haşı1, 2021b: 2325).

\section{Sonuç}

Arap ayaklanmalarının Suriye'ye sıçramasıyla rejim yanlıları ile muhalefet arasında 2011 yılında başlayan iç savaşa zamanla diş aktörler de dahil olmuş ve Suriye krizi günümüze kadar devam eden içinden çıkılmaz bir sürece doğru evrilmiştir. Kriz boyunca Esad rejiminin çökmemesi için askeri, siyasi, ekonomik ve diplomatik desteğini esirgemeyen Rusya, rejimin arkasındaki en büyük güç olmuştur. BM Güvenlik Konseyi'nde Esad rejimine karşı askeri müdahale için sebep oluşturabilecek karar tasarılarını veto eden Moskova, Şam yönetiminin varlığının muhafazası için diplomasiyi sonuna kadar kullanmıştır. Suriye'de Esad rejiminin muhalif gruplar karşısında toprak kaybederek daha küçük bir alana doğru çekilmesiyle, 2015 yılında Suriye'ye doğrudan askeri müdahalede bulunarak hava operasyonlarına başlamıştır. Moskova ve Şam arasındaki tarihsel yakınlık, Moskova'nın Washington ile sürdürdüğü küresel liderlik rekabeti, Ortadoğu bölgesindeki askeri ve ekonomik çıkarları, köktendinci radikal unsurlara karşı mücadele hedefi, Doğu Akdeniz'deki askeri varlığını korumak ve genişletmek istemesi ve Suriye'ye gerçekleştirdiği silah ihracatından dolayı Rusya Suriye'ye doğrudan müdahil olmuştur. Rusya'nın askeri müdahalesi sonrasında Suriye'deki güç dengesi Esad rejimi lehine değişmiş ve rejimin kontrol ettiği topraklar genişlemiştir.

Soğuk Savaş yıllarında, Suriye ile yaptığı anlaşmayla Akdeniz kıyılarında bir donanma üssü elde eden Rusya, iç savaş sırasında bakım ve onarım çalışmalarıyla bu üssü genişletmiştir. Rusya elde ettiği Tartus deniz üssüyle, tarih 
boyunca hep hayalini kurduğu sıcak denizlere inme firsatını yakalamış ve Akdeniz'de varlığını ilan etmiştir. Bu üs sayesinde stratejik üstünlük kazanan Rusya, Doğu Akdeniz'deki enerji mücadelesinde ağırlığını arttırmıştır. Yeni ürettiği silahları Suriye toprakları üzerinde deneyerek onları adeta görücüye çıkarmış ve gerçekleştirdiği silah ticaretiyle ekonomisini güçlendirmiştir. Lazkiye yakınlarındaki Hmeymim hava üssüyle bölgedeki askeri kapasitesini arttıran Rusya, Suriye'de büyük kazanımlar elde etmiştir. Suriye'de Esad rejiminin varlığını sürdürmesi, Moskova yönetiminin bölgedeki askeri, ekonomik ve stratejik çıkarlarını korumak için hayati önem arz etmiş̧ir. Suriye'de devam eden iç savaşı elde ettiği kazanımları koruyarak sona erdirmeyi planlayan Rusya, bölge ülkelerini yanına alarak inşa ettiği Astana ve Soçi görüşmeleriyle barış sürecini yöneten en önemli aktörlerden biri olma rolünü üstlenmiştir. Rusya, Suriye'deki iç savaşa doğrudan taraf olarak ve bölgedeki varlığını ilan ederek hem küresel ölçekte $\mathrm{ABD}$ ile sürdürdüğ̈̈ güç mücadelesinde mevzi kazanmış hem de bölgesel düzeyde Ortadoğu'da etkinliğini arttırarak çıkarlarını muhafaza etmiştir. İlk kez eski Sovyet toprakları dışında bir bölgede aktif olarak varlık gösteren Moskova, Suriye'ye yönelik izlediği politika sayesinde dünya siyasetinde sözü geçen 'büyük güç' olma firsatını yakalamıştır.

\section{Kaynaklar}

Ağır, O. \& Takar M. (2016). Rusya-Suriye İlişkilerinin Tarihsel Arka Planı. KSÜ Sosyal Bilimler Dergisi, 13(2), 285-306.

Aksoy, M. (2019). Rusya'nın Ortadoğu'ya Bakışı. Ortadoğu Analiz, 10(89), 6871.

Allison, R. (2013). Russia and Syria: Explaining Alignment With a Regime in Crisis. International Affairs, 89(4), 795-823.

Aslanl1, A. (2018). Rusya'nın Suriye Politikası. ORSAM, No 75.

Blanga, U. (2021). Syria-Russia and the "Arab Spring”: A Reassessment. Middle East Policy, 27(4), 62-82.

Bulut, S. (2020). Suriye Rejiminin Zor Y1lı: Gösteriler, Yaptırım Süreci ve Mahluf Krizi Perspektifinde Son Gelişmeleri Anlamak. ORSAM, No 134.

Canyurt, D. (2018). Kazananı Olmayan Savaş 'Suriye İç Savaşı': Neden Bitmedi, Barış Nasıl Gelebilir?. Uluslararası Yönetim İktisat ve İşletme Dergisi, 14(4), 1103-1120.

Charap, S. (2013). Russia, Syria and the Doctrine of Intervention. Survival, 55(1), 35-41.

Çalışkan, B. (2018). Vladimir Putin Dönemi Rusya'nın Suriye Politikası. Yayımlanmamış Yüksek Lisans Tezi. Marmara Üniversitesi Ortadoğu ve İslam Ülkeleri Araştırmaları Enstitüsü, İstanbul. 
Dalar, M. (2017). Rusya'nın Son Dönemdeki Suriye Politikası. 7. Uluslararası Karadeniz Sempozyumu, 168-176.

Derman, G. S. (2016). Bağımsız Devletler Topluluğu (BDT) Dönemi Rus Dış Politikası Paradigmaları. Gazi Akademik Bakış, 10(19), 283-295.

Dieckhoff, M. (2020). Reconsidering the humanitarian space: Complex interdependence between humanitarian and peace negotiations in Syria. Contemporary Securtty Policy, 41(4), 564-586.

Dilek, M. S. (2017). Rusya Federasyonu-Suriye İlişkilerinin Temelleri. Kastamonu Üniversitesi Iktisadi ve İdari Bilimleri Fakültesi Dergisi, 16(2), 58-82.

Ergun, A. (2018). Tarihsel Bağlam İçinde Rusya'nın Suriye Politikası (20122018). Yayımlanmamış Yüksek Lisans Tezi. Ankara Üniversitesi Sosyal Bilimler Enstitüsü, Ankara.

Ermağan, İ. \& Y1lmaz O. (2015). Rusya'nın Ortadoğu Politikaları. İ.K. Ülger (Ed.), Putin'in Ülkesi: Yeni Yüzyll Eşiğinde Rusya Federasyonu Analizi içinde (651-675), Ankara: Seçkin Yayınları.

Erşen, E. (2017). Rusya'nın Suriye Politikası: Firsatlar, Riskler ve Tehditler. H. B. Yalçın ve B. Duran (Ed.), Küresel ve Bölgesel Aktörlerin Suriye Stratejileri içinde (149-174), İstanbul: SETA Yayınları.

Erşen, E. (2019). Rus Dış Politikasında Ortadoğu: Arap Baharı ve Sonrası. T. Oğuzlu ve C. Çiçekçi (Ed.), Küresel ve Bölgesel Güçlerin Ortadoğu Bölgeleri, Arap Baharı ve Sonrası içinde (55-81), Ankara: Nobel Akademik Yayıncılık.

German, T. (2020). Harnessing protest potential: Russian strategic culture and the colored revolutions. Contemporary Security Policy, 41(4), 541-563.

Gülşen, H. (2018). Rusya'nın Askeri Yayılmacıllı̆ı: Gürcistan, Ukrayna ve Suriye Müdahaleleri. ORSAM, No: 218.

Haşı1, H. (2021a). YPG'nin Müttefik İkilemi: ABD mi Rusya mı?. Ortadoğu Analiz, 12(97), 58-61.

Haşıl, H. (2021b). Arap Ayaklanmalarının Bitmeyen Krizleri: Suriye Örneği. Ortadoğu Analiz, 12(98), 22-25.

Issaev, L. (2021). Russia and the New Middle East. Journal of Balkan and Near Eastern Studies, 23(3), 423-442.

İnat, K. (2019, 23 Ocak). Rusya Suriye'de $\mathrm{Ne}$ İstiyor?. https://www.setav.org/rusya-suriyede-ne-istiyor/.

İsmayılov, E. (2015). Rusya'nın Suriye Stratejisi ve Orta Doğu'da Değişen Güç Dengeleri. BILGESAM, No 1255. 
Karabulut, B. (2007). Karadeniz'den Ortadoğu'ya Uzanan Bir Dış Politika: Geçmişten Günümüze Suriye-Rusya İlişkileri. Karadeniz Araştırmaları, Say1 15, 67-88.

Kelkitli, F. A. (2016). Soğuk Savaştan Günümüze Rusya'nın Suriye Politikası. H. Çomak, C. Sancaktar ve Z. Yıldırım (Ed.), Uluslararası Politikada Suriye Krizi içinde (359-370), İstanbul: Beta Yayınları.

Kemaloğlu, İ. (2013). Ortadoğu Silah Pazarında Rusya'nın Payı. Ortadoğu Analiz, 5(55), 58-70.

Kotz, D. M. \& Weir, F. (2012). Gorbaçov'dan Putin'e Rusya'nın Yolu, Sovyet Sisteminin Çöküşü ve Yeni Rusya, İstanbul: Kalkedon Yayınları.

Köstem, S. (2017). Astana Görüşmeleri ve Rusya'nın Suriye'de Çözüme Bakış1. Ortadoğu Analiz, 9(79), 17-19.

Madouni, A. \& Derradji, H. (2020). The Caesar Law For The Protection Of Civilians In Syria: Objectives and Ramifications. Prizren Social Science Journal, 4(3), 61-68.

Maher, D. \& Pieper, M. (2020). Russian Intervention in Syria: Exploring the Nexus between Regime Consolidation and Energy Transnationalisation. Political Studies, 00(0), 1-21.

Mevlütoğlu, A. \& Korkmaz, S. C. (2020). Türkiye'nin Askeri Dönüşümü, ORSAM, No 13.

Orhan, O. (2020). Suriye Krizinin 10. Y11.. Ortadoğu Analiz, 11(93), 44-47.

Orhan, O., Haşıl, H., Dündar, S. \& Şanlıer, M. Ş. (2020). Halk Hareketinden İç Savaşa: 10. Yılında Suriye Krizi. ORSAM, No 243.

Osborn, A. \& Stewart, P. (2015, 30 Eylül). Russia Begins Syria Air Strikes in its Biggest Mideast İntervention in Decades. https://www.reuters.com/article/us-mideast-crisis-russia idUSKCNORU0MG20150930.

Örmeci, O. \& Kısacık, S. (2018). Rusya Siyaseti ve Rus Dış Politikası. Ankara: Seçkin Yayınları.

Pieper, M. (2019). Rising Power Status and the Evolution of International Order: Conceptualising Russia's Syria Policies. Europe-Asia Studies, 71(3), 365387.

Rezvani, B. (2020). Russian foreign policy and geopolitics in the Post-Soviet space and the Middle East: Tajikistan, Georgia, Ukraine and Syria, Middle Eastern Studies, 56(6), 878-899.

Roth, A. (2020, 5 Mart). Russia and Turkey agree ceasefire in Syria's Idlib province. https://www.theguardian.com/world/2020/mar/05/russia-andturkey-agree-ceasefire-in-syrias-idlib-province. 
Sağlam, M. (2013). İnadın Ötesinde: Rusya'nın Suriye Politikası. Ankara Üniversitesi SBF Dergisi, 68(4), 211-217.

Samoylov, Y (2018). Rusya'nın Suriye Politikası, Ankara: Hitabevi Yayınları.

Sarıkaya, B. (2015). Geçmişten Günümüze Suriye-Rusya İlişkileri. TASAM.

Soldatkin, V. \& Kiselyova, M. (2020, 5 Mart). Russia, Turkey agree ceasefire deal for Syria's Idlib. https://www.reuters.com/article/us-syriasecurity/russia-turkey-agree-ceasefire-deal-for-syrias-idlibidUSKBN20S161.

Souleimanov, E. A. \& Abbasov N. (2020). Why Russia Has Not (Yet) Won Over Syria and Libya. Middle East Policy, 27(2), 81-93.

Souleimanov, E. A. \& Dzutsati, V. (2018). Russia's Syria War: A Strategic Trap?. Middle East Policy, 25(2), 42-50.

Syria conflict: War of words as peace talks open in Astana. (2017, 24 Ocak). https://www.bbc.com/news/world-middle-east-38714441. Erişim Tarihi: 09.12.2020.

Syria: Latest round of talks on constitution begins in Geneva. (2021, 25 Ocak). https://www.aljazeera.com/news/2021/1/25/fresh-round-of-talks-onsyrias-constitution-begins-in-geneva. Erişim Tarihi: 15.03.2021.

Syrian Democratic Council and Popular Will Party sign memorandum on resolving Syrian crisis in Moscow. (2020, 31 Ağustos). https://npasyria.com/en/46085/. Erişim Tarihi: 20.03.2021.

Tellal, E. (2010). Zümrüdüanka: Rusya Federasyonu'nun D1ş Politikası. Ankara Üniversitesi SBF Dergisi, 65(3), 189-236.

Tsvetkova, M. (2018, 17 Eylül). Russia and Turkey agree to create buffer zone in Syria's Idlib. https://www.reuters.com/article/us-mideast-crisis-putinerdogan-hope-idUSKCN1LX1BU.

Unnikrishnan, N. \& Purushothaman, U. (2017). Russia in Middle East: Playing the Long Game?. India Quarterly, 73(2), 251-258.

Yılmaz, S. (2016). Rusya Neden Suriye'de?. Ankara: Yazar Yayınları.

Zvyagelskaya, I. (2018). Russian Policy in the Levant. Uluslararası İlişkiler, 15(60), 121-133. 